KRZYSZTOF FOKT

\title{
Książęta i namiestnicy. Historycznoustrojowa glossa do Janusza Bieniaka wizji ustroju drugiej monarcbii piastowskiej $^{1}$
}

\author{
Abstract \\ Princes and Governors: The Legal-Historical Glossa to the Janusz Bieniak's \\ Conception of a Constitutional Order in the Second Piasts' Monarchy
}

In the paper, an attempt of eliminating a certain supposed internal contradiction in the concept of Janusz Bieniak concerning the role and position of junior members of the Piast dynasty in the territorial governance of the so called second Polish monarchy (ca 1040-1177) was undertaken. As the result of the conducted reasoning, three probable and one hypothetic model of engaging the junior Piasts in the management of provinces were discerned, two of which (1. and 2.) included co-existence in a given province of a Piast duke and a noblemen appointed by the "grand duke" (princeps), and two: officiating of sole members of the dynasty as governors or rulers in the provinces of the monarchy. All those models must be taken into account in further research on the constitutional and political history of the Piast state in the eleventh and twelfth centuries.

Keywords: history of government, Piast dynasty, Poland, Middle Ages, territorial governance.

Słowa klucze: historia ustroju, dynastia Piastów, Polska, średniowiecze, zarząd terytorialny.

Pisanie o historii ustroju drugiej monarchii Piastów jest obecnie, z racji wielkiej liczby poruszających ten temat opracowań oraz braku nowych źródeł, działalnością wybitnie glossatorską. Każdy tekst dotyczący tych zagadnień, jeśli sam nie przynosi rewolucji w stanie naszej wiedzy, stanowi swego rodzaju duży przypis do innych prac, które zdeterminowały „aksjomatykę" dotychczasowych badań. Nie inaczej niniejszy przyczynek, będący sui generis glossą do koncepcji Janusza Bieniaka. Autorowi temu zawdzięcza nauka historyczna lakonicznie przedstawioną, a zarazem całkiem dopracowaną wizję ustroju drugiej monarchii piastowskiej. Wizja ta zasadza się na założeniu jedności tej

1 Autor wyraża wdzięczność prof. Stanisławowi Grodziskiemu, dr. Maciejowi Mikule oraz P.T. Recenzentom niniejszego artykułu za trud lektury jego roboczych wersji oraz konstruktywne do nich uwagi. 
monarchii do co najmniej 1177 r., niezaburzonej przez wydzielanie Piastowicom dzielnic. Według Bieniaka członkowie rodziny panującej sprawowali władzę w poszczególnych prowincjach nie jako ich dziedziczni władcy, lecz jako namiestnicy księcia zwierzchniego (princepsa) $)^{2}$.

Koncepcja ta, w znacznej mierze oparta na analogiach z dobrze źródłowo oświetlonej Rusi, choć słusznie doczekała się szerokiej akceptacji w nauce ${ }^{3}$, zawiera jednak pewną istotną sprzeczność wewnętrzną. Z jednej strony, według Bieniaka bracia i synowie panujących książąt mieli rządzić prowincjami jako ich namiestnicy, podobnie jak młodsi Rurykowicze. Zarazem jednak, zdaniem toruńskiego mediewisty, obok nich mieliby działać dotychczasowi włodarze prowincji, ich komesi. Z perspektywy lat 80 . $\mathrm{XX}$ w., gdy powstawało opracowanie Bieniaka, sprzeczność ta nie była jeszcze rażąca ze względu na powszechne w historiografii utożsamienie komesów ze znanymi z okresu rozbicia dzielnicowego kasztelanami. Dopiero późniejsze prace przyczyniły się do obalenia przyjmowanego dotąd za aksjomat założenia tożsamości komesów drugiej monarchii z kasztelanami znanymi z księstw dzielnicowych ${ }^{4}$. W takim razie jednak, skoro $\mathrm{w}$ drugiej monarchii nie istniała osobna, powiązana $\mathrm{z}$ grodową, struktura kasztelańska, nie widać powodu, dla którego książęta piastowscy mieliby współistnieć z jakimiś namiestnikami prowincji, a nie po prostu, jak na Rusi, sami występować jako namiestnicy (w miejsce „posadników” z grona możnowładztwa). Idea dualizmu administracyjnego - tak bowiem należałoby w pojęciach współczesnej administratywistyki określić współwystępowanie dwóch urzędników wysokiego szczebla w jednej prowincji - nieznana była w owym czasie także w innych monarchiach „młodszej Europy”, za to praktykowano ją z powodzeniem w Niemczech, gdzie obok książąt i grafów działali królewscy

2 Koncepcję swą przedstawił Bieniak, odwołując się przede wszystkim do wcześniejszego studium Jerzego Dowiata (Polska - państwem średniowiecznej Europy, Warszawa 1968, s. 223-252) w pierwszej części swego wieloczęściowego studium o polskiej elicie politycznej XII w. (J. Bieniak, Polska elita polityczna XII wieku, cz. 1: Tło działalności [w:] Społeczeństwo Polski średniowiecznej, t. 2, red. S.K. Kuczyński, Warszawa 1982, s. 29-61) oraz opatrzył autorskimi glossami i dodatkową argumentacją w dalszych częściach tego opracowania i w innych swych tekstach (zob. szczególnie J. Bieniak, Powstanie księstwa opolsko-raciborskiego jako wyraz przekształcania się Polski w dzielnicowa poliarchię [w:] Sacra Silentii provincia. 800 lat dziedzicznego księstwa opolskiego (1202-2002), red. A. Pobóg-Lenartowicz, Opole 2003, s. 37-81, tam dalsze odsyłacze).

3 Por. opinię Sławomira Gawlasa, O ksztalt zjednoczonego Królestwa. Niemieckie władztwo terytorialne a geneza społeczno-ustrojowej odrębności Polski, wyd. 2, Warszawa 2000, s. 78, a także zgodne zdania recenzentów niedawno wydanej książki Jacka Osińskiego, w której autor podjął daremną próbę podważenia koncepcji Bieniaka: Tomasza Jurka ([rec.:] Jacek Osiński, Statut Bolestawa Krzywoustego, Wydawnictwo Avalon, Kraków 2014, ss. 272, „Roczniki Historyczne” 2015, R. 81, s. 232, passim) i Mateusza Kosonowskiego (O ustawie sukcesyjnej Bolestawa Krzywoustego w kontrowersyjnym oświetleniu. W zwiazku z praca Jacka Osińskiego Statut Bolesława Krzywoustego, Wydawnictwo Avalon, Kraków 2014, ss. 271 i 5 tablic, CPH 2015, t. 67, nr 2, s. 268-269).

4 T. Wasilewski, Poland's Administrative Structure in Early Piast Times. Castra Ruled by Comites as Centres of Provinces and Territorial Administration, Acta Poloniae Historica 1989, vol. 44, s. 5-31; M. Cetwiński, Kasztelanowie i kasztelanie na Ślasku w XIII i XIV wieku [w:] Studia z dziejów średniowiecza polskiego i powszechnego, Acta Universitatis Wratislaviensis 1989, t. 979, „Historia”, t. 69, Wrocław, s. 3-20; S. Gawlas, O ksztatt zjednoczonego Królestwa ..., s. 74-75; por. także: K. Fokt, Denuo de Legenicensi potestate: uwagi o znaczeniu Legnicy w księstwie Bolesława Wysokiego, „Śląski Kwartalnik Historyczny Sobótka” 2015, R. 70, nr 2, s. 5-6.

Artykuły - Articles 
pfalcgrafowie i burgrafowie ${ }^{5}$. Czyżby więc druga monarchia Piastów była jedynym obok Niemiec państwem Europy Środkowo-Wschodniej, w którym zdecydowano się sięgnąć po ów dualistyczny wzorzec organizacji zarządu terytorialnego?

\section{Model I: Książę i „pfalcgraf”}

Śladem możliwej inspiracji Piastów niemieckim wzorcem terytorialnych palatynatów (Pfalzgrafschaften) jest sytuacja opisana w kronice Anonima zwanego Gallem, gdy Władysław Herman wydzielił synom dzielnice, lecz sedes Regni principales de manu sua non dimisit ${ }^{6}$. Jest to - niesłusznie bagatelizowany przez niektórych badaczy ${ }^{7}-$ całkiem jasny opis stworzenia przez władcę dwóch równoległych pionów zarządu terytorialnego: książę zwierzchni wydzielił wprawdzie dzielnice synom, zachował jednak władzę nad niektórymi przynajmniej sedibus Regni. W kronice Anonima chodzi przy tym o rezydencje przez dziejopisa nazwane głównymi: Kraków, Wrocław i Sandomierz. Spośród nich, jak można wnioskować z lektury innej partii kroniki ${ }^{8}$, tylko Wrocław nie pozostał pod bezpośrednią władzą Władysława, lecz stał się głównym grodem dzielnicy jego młodszego syna ${ }^{9}$. W grodzie tym urzędował wówczas komes Wojsław, któremu zlecona została opieka nad najmłodszym synem księcia. Opis późniejszych wydarzeń, w których Wojsław odegrał - być może mimowolnie - dość dwuznaczną rolę, wskazuje jednak, że opieka nad młodym Bolesławem nie była jedynym (a może nawet nie była głównym) obowiązkiem komesa. Rzuca się bowiem w oczy, że Wojsław, choć piastun, nie wybrał się z Bolesławem na zwołaną przez Władysława wyprawę przeciw Czechom (czytając odnośny ustęp Galla można wręcz nabrać wątpliwości, czy został on w ogóle powiadomiony o tym przedsięwzięciu), a do Wrocławia przybył już po wyruszeniu

5 O burgrafach ogólnie zob. Th. Zotz, Burggraf [w:] Handwörterbuch zur deutschen Rechtsgeschichte, wyd. 2, t. 1, szp. 766-768. O burgrafschaftach wschodnioniemieckich w czasach dynastii salickiej i Sztaufów por. także w pracach przywołanych niżej, w przyp. 30. O pfalcgrafach: I. Eberl, Pfalzgraf [w:] Lexikon des Mittelalters, t. 6, szp. 2011-2013; H.-W. Strätz, Pfalzgraf [w:] Handwörterbuch zur deutschen Rechtsgeschichte, wyd. 1, t. 3, 1667-1670; por. także nowszą pracę o urzędzie palatyna na przykładach bawarskich: Ch. Paulus, Das Pfalzgrafenamt in Bayern im frühen und hohen Mittelalter, Kommission für bayerische Landesgeschichte: Studien zur bayerischen Verfassungs- und Sozialgeschichte, Arbeiten aus der historischen Atlasforschung in Bayern, t. 25, München 2007.

${ }_{6}$ Galli Anonymi cronica et gesta ducum sive principum Polonorum, wydał, wstępem i koment. opatrzył K. Maleczyński, Monumenta Poloniae Historica, Series II, t. 2, Kraków 1952, II, 7, s. 74.

7 Znamienne jest tu sformułowanie Janusza Bieniaka, w świetle którego decyzja Hermana o zatrzymaniu samych grodów rozbijałaby „naturalną całość, jaką stanowił naczelny gród wraz z podlegającym mu terytorium”, i stwarzała „niewyobrażalne trudności administracyjne”. J. Bieniak, Polska elita..., cz. 1, s. 20, przyp. 44. W sąsiednich Niemczech owe rzekomo niewyobrażalne trudności nie powstrzymały przecież Henryka IV ani przed utrzymaniem palatynów w terytoriach, ani przed powołaniem burgrafa w Miśni; nie widać też powodów, by przeprowadzenie podobnego zabiegu w Polsce miało przekraczać intelektualne zdolności ówczesnych Polaków i logistyczne możliwości monarchii Piastów.

8 Galli Anonymi cronica..., II, 16, s. 83: Bolesław miał zająć Kraków i Sandomierz i odebrać tam przysięgi wierności od mieszkańców.

9 Por. G. Labuda, Władysław i Zbigniew. U genezy podziałów dzielnicowych w Polsce w drugiej połowie XI wieku [w:] Społeczeństwo Polski średniowiecznej, t. 6, red. S.K. Kuczyński, Warszawa 1994, s. 17-18, przyp. 23. 
i przedwczesnym powrocie księżyca, i to de servicio suo ${ }^{10}$. Wygląda więc na to, że Władysław Herman, wydzielając dzielnicę Bolesławowi, postawił przy nim zaufanego komesa, który miał nie tylko sprawować opiekę nad młodym księciem, lecz także pilnować w terenie interesów władcy zwierzchniego ${ }^{11}$.

Niestety w dziejach drugiej monarchii piastowskiej brak pewnych analogii do sytuacji omówionej wyżej: „kohabitacji” dynasty i komesa - „pfalcgrafa”. Jeżeli któregokolwiek z późniejszych Piastów można podejrzewać o sięgnięcie po podobny wzorzec postępowania - wydzielenie synowi dzielnicy z pozostawieniem nadzoru nad interesami władcy zwierzchniego w danym terytorium w rękach zaufanego komesa - to mógłby to być jedynie Władysław II w okresie, gdy rządy na Śląsku sprawował w jego imieniu najstarszy syn Bolesław Wysoki ${ }^{12}$; komesem sprawującym wówczas rządy we Wrocławiu z ramienia księcia zwierzchniego byłby oczywiście Piotr Włostowic. Chcąc udowodnić, że było tak w istocie, należałoby jednak wykazać, że: (1) w okresie rządów na Śląsku Bolesława Wysokiego z ramienia ojca Piotr był w istocie komesem wrocławskim (równolegle do palacji ogólnopolskiej bądź nie będąc wówczas wojewodą - kwestia ta jest w nauce dyskusyjna ${ }^{13}$ ); (2) funkcja Piotra była w swej istocie zbliżona do funkcji Wojsława w czasach wrocławskich rządów Bolesława Krzywoustego. Obydwie te tezy wymagają osobnego dowodu, a jedynym źródłem wspierającym je wprost jest passus rękopisu królewieckiego Kroniki polskiej (tzw. polsko-śląskiej), w którym Piotr został obdarzony zaskakującą tytulaturą comes tocius Polonie et pallacii Wratislaviensis (co najprościej można zinterpretować jako kumulację palacji ogólnopolskiej z domniemanym „pfalcgrafschaftem” wrocławskim) ${ }^{14}$. Argument ten jest jednak zbyt słaby, by budować na nim dalsze hipotezy; udowodnienie, że Władysław II administrował Wrocławiem w systemie dwutorowego zarządu, zrekonstruowanym powyżej dla wcześniejszych rządów dzielnicowych Bolesława Krzywoustego, wymagałoby precyzyjnego skorygowa-

10 Galli Anonymi cronica..., II, 16, s. 82.

11 O dwoistym charakterze funkcji komesa Wojsława por. A. Krawiec, Król bez korony. Władysław I Herman, książę polski, Warszawa 2014, s. 240.

12 Hipoteza rządów namiestniczych Bolesława Wysokiego na Śląsku za panowania ojca jest oparta na dowodach pośrednich, jednak dostatecznie wymownych. Por. J. Bieniak, Polska elita ..., cz. 1, s. 42-44.

13 Por. przegląd opinii u J. Sporsa, Wojewodowie Polski dzielnicowej w XII i XIII wieku: Przegląd wojewodów w kontekście ewolucji urzędu od godności nadwornej do urzędu ziemskiego, „Przegląd Historyczny” 1991, R. 82, nr 3-4, s. 363; oraz J. Bieniaka, Polska elita polityczna XII wieku, cz. IVB: Dwa możnowładztwa - starszy i nowi [w:] Społeczeństwo Polski Średniowiecznej. Zbiór studiów, t. 12, red. S. Górzyński, Warszawa 2012, s. 30-31; tam odsyłacze do źródeł i dalszego piśmiennictwa. Bezdyskusyjne jest jedynie sprawowanie przez Piotra palacji przy Bolesławie IV (por. tu szczególnie dobitnie: J. Spors, Wojewodowie Polski dzielnicowej..., s. 364; J. Wenta, O stróżach „,testamentu” Bolesława Krzywoustego [w:] Społeczeństwo Polski średniowiecznej, t. 8, red. S.K. Kuczyński, Warszawa 1999, s. 100-105).

14 Kronika Polska (Chronica Polonorum), wyd. L. Ćwikliński, Monumenta Poloniae Historica, t. 3, Lwów 1878, s. 628. O możliwym sprawowaniu wówczas przez Piotra i palacji ogónopolskiej, i namiestnictwa we Wrocławiu: J. Spors, Wojewodowie Polski dzielnicowej..., s. 363-364. Za nieuprawniony uznać należy zarzut J. Bieniaka, Polska elita polityczna XII wieku, cz. IIIA: Arbitrzy książat - krąg rodzinny Piotra Włostowica [w:] Społeczeństwo Polski średniowiecznej, t. 4, red. S.K. Kuczyński, Warszawa 1990, s. 33, jakoby taka kumulacja sprawiała, iż ,jeden z tych urzędów nie byłby w danym razie funkcjonalny". Urzędy ówczesne były nie tylko funkcjami, lecz także, a nawet przede wszystkim, godnościami (por. Th. Zotz, Im Amt und Würden: Zur Eigenart ,, offizieller”. Positionen im früheren Mittelalter, ,Tel Aviver Jahrbuch für deutsche Geschichte" 1993, nr 22, s. 1-23) i wydaje się wręcz nieprawdopodobne, by Piotr w związku z awansem na palację zrezygnował ze swej pozycji we Wrocławiu, mozolnie i z wielkim nakładam budowanej m.in. poprzez bezprecedensowe w skali Polski fundacje. 
nia historii Polski i Śląska w latach 1138-1145 oraz biografii Piotra Włostowica, co z pewnością nie jest celem i nie mieści się w ramach niniejszego szkicu.

\section{Model II: Książę i namiestnik}

Odmienny od powyżej opisanego wzorzec koegzystencji księcia dzielnicowego i namiestnika-możnowładcy zastosowany został podczas pierwszego buntu Zbigniewa, gdy przybywszy z Czech, został on przyjęty we Wrocławiu przez tamtejszego namiestnika Magnusa. Z kroniki Anonima zwanego Gallem dowiadujemy się, że rządy Zbigniewa we Wrocławiu zostały przynajmniej na pewien czas uznane przez Władysława Hermana. Powstała $\mathrm{w}$ ten sposób sytuacja szczególna: urzędującemu namiestnikowi prowincji „przydano” piastowskiego dynastę ${ }^{15}$. W porównaniu z późniejszą sytuacją opisaną wyżej - współistnienia we Wrocławiu młodego księcia Bolesława i komesa Wojsława - mielibyśmy tu zapewne do czynienia z większym stopniem decentralizacji. Sięgając po terminologię kroniki Anonima, można rzec, że w przypadku pierwszego buntu Zbigniewa książę Władysław sedem Wratislaviensem de manu sua dimisit: nie wydaje się bowiem możliwe, by skuteczne wypromowanie pretendenta do roli księcia dzielnicowego mogło skończyć się dla Magnusa obniżeniem jego pozycji czy zmniejszeniem kompetencji, zarazem jednak trudno zakładać, że nowo kreowany książę dzielnicowy miałby uzyskać status wyraźnie gorszy od pierwszego dostojnika swej dzielnicy. Innymi słowy, odmiennie niż w późniejszym okresie, gdy księciem wrocławskim został młody Bolesław Krzywousty, podczas pierwszego buntu Zbigniewa Władysław Herman zmuszony był zapewne przystać na całkowitą decentralizację władzy, tzn. nie tylko nie postawił obok swego starszego syna komesa nadzorcy, lecz także musiał się zgodzić na koegzystencję księcia i komesa de facto niezależnych od niego samego. W praktyce musiało to oznaczać przede wszystkim decentralizację skarbowości - należy bowiem domniemywać, że skoro Magnus zachował swą pozycję, to na użytek nowo kreowanego księcia dzielnicowego przeznaczono (przynajmniej częściowo) dochody dotychczas przypadające władcy zwierzchniemu ${ }^{16}$.

15 Galli Anonymi cronica..., II, 4, s. 71. Kronikarz nie określił niestety statusu Zbigniewa jednoznacznie, stąd szereg badaczy w ogóle zaprzecza, jakoby Zbigniew po uznaniu przez ojca stał się księciem wrocławskim (tak np. H. Łowmiański, Początki Polski, T. VI: Polityczne i spoleczne procesy ksztaltowania się narodu do poczatku wieku XIV, cz. 1, Warszawa 1985, s. 117-119; K. Benyskiewicz, Władystaw Herman. Ksiażę Polski 1079-1102, Kraków 2014, s. 143). Nie sposób jednak inaczej interpretować koniunkcji znanych z kroniki faktów: uznania pierworodnego przez ojca, jego pozostawania we Wrocławiu oraz intencji obrony przezeń swej pozycji w stolicy Śląska, udaremnionej przez odstępstwo możnych; stąd znaczna część badaczy słusznie, jak sądzę, przyjęła za oczywisty książęcy status Zbigniewa (tak m.in. R. Grodecki, Zbigniew ksiązę Polski [w:] Studja staropolskie. Ksiegga ku czci Aleksandra Brücknera, Kraków 1928, s. 86; K. Maleczyński, Ślask w okresie od schyłku IX do połowy XII wieku [w:] Historia Ślaska, T.1. Do roku 1763, Cz. 1. Do połowy XIV w., red. K. Maleczyński, s. 210; J. Bieniak, Polska elita..., cz. I, s. 46; G. Labuda, Władysław i Zbigniew..., s. 14-16, przyp. 18; R. Żerelik, Dzieje Ślaska do 1526 roku [w:] Historia Ślaska, red. M. Czapliński, Wrocław 2002, s. 43; Z. Dalewski, Modele władzy dynastycznej w Europie Środkowo-Wschodniej we wcześniejszym średniowieczu, Warszawa 2014, s. 254; tam dalsze odsyłacze).

16 O podziale dochodów z prowincji między księcia dzielnicowego lub namiestnika możnowładcę a władcę zwierzchniego nie donoszą żadne źródła z czasów drugiej monarchii piastowskiej (por. K. Modze- 
Podobnie jak w odniesieniu do wyróżnionego wyżej pierwszego modelu koegzystencji książąt i namiestników, oprócz jednego przykładu z kroniki Anonima zwanego Gallem nie sposób przytoczyć dalszych pewnych przypadków zastosowania tego wzorca w praktyce politycznej drugiej monarchii piastowskiej. Strukturalnego podobieństwa do omawianego tu modelu II można jedynie dopatrzyć się w pewnym kazusie z samego schyłku istnienia jednolitej monarchii Piastów: „kohabitacji” na Mazowszu księcia Leszka Bolesławica i komesa Żyry Januszowica. Punkt wyjścia stanowiło w tym przypadku „Zwykłe” namiestnictwo Żyry na Mazowszu (w tej roli wystąpił on już prawdopodobnie w $1161 \mathrm{r}^{17}$ ); następnie, za pierwszych rządów Mieszka III i w początkach panowania Kazimierza II, możnowładca ten zawiadywał nadal prowincją w okresie małoletniości Leszka Bolesławica, wreszcie występował jako wojewoda mazowiecki przy dorosłym już księciu ${ }^{18}$. Nie sposób przyjąć z góry, że formalna pozycja komesa Żyry pod rządami trzech princepsów nie ulegała zmianie. Skoro jednak mazowiecki możny zaczynał swą karierę od namiestnictwa prowincji, a następnie dołączył doń małoletni książę, można się domyślać zastosowania w tym przypadku wyróżnionego tu modelu II.

W odniesieniu do obydwu przytoczonych wyżej przykładów zastosowania II modelu rządów piastowskich juniorów w prowincjach monarchii (Zbigniewa i Magnusa oraz Leszka i Żyry) można się zastanawiać, czy aby nie ilustrują one jedynie pewnych doraźnych rozwiązań, wymuszonych na uczestnikach przez bieg wydarzeń. Wydaje się jednak, że idea „zdublowanego namiestnictwa” mogła być, paradoksalnie, atrakcyjna z perspektywy książąt zwierzchnich, pozwalając im utrzymać stan równowagi w elicie władzy - tj. zapewnić uposażenie Piastowicom (kosztem, zapewne, udziału princepsa w dochodach z prowincji) bez potencjalnie niepopularnego rugowania możnowładztwa z lukratywnych godności terytorialnych. Sytuację taką zdaje się odzwierciedlać datacja dokumentu biskupa wrocławskiego Roberta z 1139 r., wymieniająca wszystkich uposażonych wówczas dzielnicami synów Bolesława III jako współrządzących państwem ${ }^{19}$ :

lewski, Chłopi w monarchii wczesnopiastowskiej, Wrocław 1987, T. 1 serii Chłopi w społeczeństwie polskim, red. Cz. Madajczyk, s. 143, przyp. 29), jednak zastosowanie tego praktycznego rozwiązania także w Polsce przed 1177 r. jest wysoce prawdopodobne zarówno ze względu na współczesne analogie z innych państw (szczególnie Niemiec, Węgier, Chorwacji i Rusi, por. K. Modzelewski, Organizacja gospodarcza państwa piastowskiego: X-XIII wiek, wyd. 2, Poznań 2000, s. 92-94, 152; M. Font, Im Spannungsfeld der christlichen Großmächte. Mittel- und Osteuropa im 10.-12. Jahrhundert, Herne 2008, s. 137-139; M.F. Kotljar, V.M. Rička, Knjažyj dvir Pivdennoj Rusi X-XIII st., Kyiv 2008, s. 194-195), jak i postać najdawniejszego uposażenia biskupstw polskich (zob. K. Modzelewski, Organizacja..., s. 93-94, passim) i późniejsze dane dotyczące Polski dzielnicowej (por. ibidem, s. 113-114, 182, passim; F. Dąbrowski, Studia nad administracja kasztelańska Polski XIII wieku, Warszawa 2007, s. 44).

17 Zob. Liber formularum ad ius canonicum spectantium, ex actis Jacobi de Kurdwanow episcopi Plocensis maxima parte depromptarum, wyd. B. Ulanowski, Archiwum Komisji Prawniczej, t. 1, nr 29, s. 35.

18 Ewolucję tę ilustruje zmiana terminologii w IV księdze Kroniki Polskiej Mistrza Wincentego, gdzie w rozdziale 8 Żyra wystąpił jeszcze jako preses provinciarum, a już w rozdziale 13 jako procurator Lestconis ac militie princeps (Magistri Vincentii dicti Kadlubek Chronica Polonorum, ed. M. Plezia, Monumenta Poloniae Historica, Series II, t. 9, Kraków 1994, s. 147, 155; por. także: J. Bieniak, Polska elita..., cz. I, s. 19; cz. IVB, s. 33, 38).

19 Schlesisches Urkundenbuch, t. 1: 971-1230, hrsg. J.J. Menzel, H. Appelt, bearb. H. Appelt, KölnGraz 1963 (dalej: SUB), nr 19: Boleslao tercio Polonie principe defuncto, regnantibus pro eo filiis eius Wladislao in Cracouia, Boleslao in Mazouia, Misicone in Poznania. Dokument został najpewniej spisany dopiero w 1149 r., ale odzwierciedla dość ściśle realia o 10 lat wcześniejsze (por. komentarz wydawcy SUB, t. 1). $\mathrm{O}$ władczym raczej niż namiestniczym statusie wymienionych w dokumencie książąt por. H. Łowmiański, 
nie można wykluczyć, że ów triumwirat wspólnie pobierał jakąś część dochodów władzy zwierzchniej z prowincji i w związku z tym był w stanie pozostawić w tychże prowincjach namiestników-możnowładców ${ }^{20}$. Niewykluczone zatem, że opisywany tu model II, „zdublowanego namiestnictwa”, był stosowany częściej, niż można się tego domyślać na obecnym etapie badań.

\section{Model III: „czyste" namiestnictwo}

Spośród kilkunastu przykładów równoległego urzędowania książąt i komesów w drugiej monarchii piastowskiej, zebranych niedawno przez Janusza Bieniaka ${ }^{21}$, nie sposób wyróżnić dalszych, które można by przyporządkować któremukolwiek z wyróżnionych wyżej modeli „kohabitacji”. Przyczyną tych trudności jest uboga i niełatwa w interpretacji podstawa źródłowa, na którą składają się przede wszystkim testacje dwunastowiecznej proweniencji, nieraz luźno dołączone do późniejszych falsyfikatów, których egzegeza zależy zawsze od przyjętego klucza - tego zaś dostarczyć mogą jedynie dalsze, pogłębione badania nad polityczną i ustrojową historią Polski w XII w. Nawet bez dodatkowych, specjalnych studiów można jednak stwierdzić, że obok obydwu opisanych wyżej modeli koegzystencji piastowskich książąt krwi i namiestników-możnowładców w drugiej monarchii Piastów znany był także „czysty” model namiestniczy, w którym książęta dzielnicowi występowali po prostu na równi z komesami (odpowiednikami ruskich posadników) możnowładczej kondycji.

Z ustępu kroniki Anonima zwanego Gallem, który opowiada o wydzieleniu dzielnic obydwu synom przez starego Władysława Hermana, można dowiedzieć się nie tylko o specyficznej sytuacji Bolesława, którego stolicy - Wrocławia - ojciec de manu sua non dimisit, lecz także o zgoła odmiennym statusie Zbigniewa. Stolicy działu starszego syna - zapewne Gniezna - stary książę nie pozostawił bowiem w swym ręku ${ }^{22}$. Należy

Rozdrobnienie feudalne Polski w historiografii naukowej [w:] Polska $w$ okresie rozdrobnienia feudalnego, red. H. Łowmiański, Wrocław 1973, s. 31-32; J. Spors, Podział dzielnicowy Polski wedtug statutu Bolesława Krzywoustego ze szczególnym uwzględnieniem dzielnicy seniorackiej, Słupsk 1978, s. 114; por. także polemikę J. Bieniaka, Polska elita..., cz. I, s. 49-50.

20 Brak pewnych informacji o udziale książąt juniorów w dochodach przypadających normalnie władcy zwierzchniemu w czasach Bolesława IV; z całą pewnością książę ten zachowywał monopol menniczy, zarazem jednak istnieją przesłanki, że jego młodsi bracia mogli mieć pewien udział w pozyskiwanych w ziemi krakowskiej zasobach soli. Por. M. Biniaś-Szkopek, Bolesław Kędzierzawy, Poznań 2014, s. $239-241$.

21 Toruński mediewista zestawił odnośne dane w swej liście urzędników XI i XII w., stanowiącej aneks do ostatniej części Polskiej elity politycznej XII wieku, cz. IVB (jw., przyp. 11), s. 28-43. Do listy tej należałoby zapewne dodać także nieuznawany przez tego autora (zob. J. Bieniak, Polska elita..., cz. IIIA, s. 33) kazus równoległego urzędowania we Wrocławiu Bolesława Wysokiego i Piotra Włostowica, o czym wyżej.

22 Por. tu przeciwne zdanie G. Labudy (Władysław i Zbigniew..., s. 20), niepoparte jednak żadnym uzasadnieniem. Nie przekonuje także próba podważenia tej tezy podjęta przez Karola Maleczyńskiego, Bolesław Krzywousty. Zarys panowania, Kraków 1947, s. 23-24, oparta na założeniu, że Gall interesował się wyłącznie dzielnicą Bolesława; nie wydaje się prawdopodobne, by kronikarz przemilczał fakt rzucający niekorzystne światło na pozycję Zbigniewa (zatrzymanie także jego grodów przez ojca in manu sua), a podał podobny w odniesieniu do Bolesława. Cała logika opowiadania Gallowego jest odwrotna: koncepcja sedes regni principales została zapewne po to tylko wykoncypowana, by wytłumaczyć czytelnikowi/słuchaczowi, 
zatem przyjąć, że Zbigniew został namiestnikiem prowincji wielkopolskiej bez dodatkowego obciążenia w postaci komesa „opiekuna”, co ustawiało go w korzystniejszej pozycji niż młodszego brata ${ }^{23}$. Tę dysproporcję próbował kronikarz zaciemnić, nazywając południowe sedes Regni głównymi, co uzasadnić miało zatrzymanie przez Władysława bezpośredniego wpływu na rządy we Wrocławiu (przez osobę komesa Wojsława). Także w późniejszym okresie, już po śmierci ojca i zwycięstwie brata w wojnie domowej, Zbigniew dzierżył Mazowsze niczym zwykły namiestnik: sicut miles, non ut dominus ${ }^{24}$.

Niewykluczone, że do tego samego modelu nawiązano w kolejnych generacjach Piastów, jeszcze przed dekompozycją jednolitej monarchii. W historiografii zwrócono uwagę, że w przeciwieństwie do Bolesława IV i Mieszka III przynajmniej przez część swego panowania ich młodszy brat Henryk sprawował w Sandomierskiem dominium, a nie ducatus, co może odzwierciedlać odmienny status tego księcia od jego starszych braci ${ }^{25}$. Prawdopodobnie także „zwykłe” namiestnictwo na Śląsku otrzymał po swym powrocie z wygnania Bolesław Wysoki; w każdym razie nie istniał pod jego rządami żaden równolegle doń działający komes wrocławski. Poucza o tym nie tylko brak wzmianek o takowym, lecz także inny niż w pozostałych dzielnicach rozwój na Śląsku głównego urzędu dworskiego (komornika-palatyna) - wywodzącego się zapewne od komornika dworu książęcego ${ }^{26}$, a nie z urzędu równoległego do księcia namiestnika prowincji, jak występowało to np. na Mazowszu pod rządami Leszka Bolesławica, gdzie komes Żyra z namiestnika prowincji stał się wojewodą. Co więcej, aż do 1177 r. książę zwierzchni zachował daleko posunięte uprawnienia w dzielnicy wrocławskiej, skoro w 1175 r. mógł sobie pozwolić na traktowanie lubiąskiego domu zakonnego cystersów jako własnej fundacji, a jego rzeczywistego fundatora, księcia Bolesława - jako klasztornego wójta ${ }^{27}$.

że pozycja Bolesława była nie gorsza niż Zbigniewa (tak w ks. II, rozdz. 7) bądź wręcz lepsza (tak w ks. II, rozdz. 8), choć spod retorycznych zwrotów kronikarza wyziera odmienny obraz: słabszej pozycji młodszego $\mathrm{z}$ braci podczas pierwszego podziału oraz równego projektowanego statusu i stanu posiadania obydwu na wypadek śmierci ojca.

23 Dysproporcję tę dostrzegł już Roman Grodecki (Zbigniew..., s. 89-90), oceniając moim zdaniem słusznie tendencję kronikarza, ale niewłaściwie zasięg dzielnic braci. Krytycznie o koncepcji Grodeckiego m.in. K. Maleczyński, Bolesław Krzywousty..., s. 23-24 (do krytyki tegoż por. y przyp. 21); A. Krawiec, Król bez korony..., s. 239-240.

24 Galli Anonymi cronica..., II, 38, s. 109.

25 T. Lalik, Sandomierskie we wcześniejszym średniowieczu. Prowincja, księstwo, województwo [w:] Studia sandomierskie. Materiały do dziejów miasta Sandomierza i regionu sandomierskiego, red. T. Wąsowicz, J. Pazdur, Warszawa 1967, s. 70-75. Por. także uwagi Agnieszki Teterycz-Puzio, Henryk Sandomierski: Polski krzyżowiec (1126/1133 - 18 X 1166), wyd. 2, Kraków 2015, s. 55-59 (gdzie dalsze odsyłacze do źródeł i piśmiennictwa). Sceptycznie o hipotezie odmiennego statusu formalnego Henryka i jego starszych braci: M. Biniaś-Szkopek, Bolesław Kędzierzawy..., s. 201-202.

26 O odmienności Śląska od pozostałych dzielnic i urzędzie komornika dworu książąt dzielnicowych zob. J. Spors, Uwagi nad geneza urzędu wojewody dzielnicowego w Polsce XII - poczatku XIII wieku, „Przegląd Historyczny” 1991, R. 82, z. 2, s. 205-206; idem, Ze studiów nad urzędami w Polsce XI i XII w. (wojewoda, komornik, podkomorzy), CPH 1992 (wyd. 1993), t. 44, z. 2:, s. 35-36.

27 Zob. SUB, t. 1, nr 49. Por. J. Bieniak, Polska elita..., cz. 1, s. 60 (autor ten widzi w uprawnieniach Mieszka III odzwierciedlonych w tym dokumencie wyraz niezmiennie do tego czasu wysokiej pozycji księcia zwierzchniego wobec władców dzielnicowych; odmienną interpretację przedstawił Przemysław Wiszewski, przypuszczając, że faktyczne przywrócenie zwierzchności princepsa nad Śląskiem zostało dokonane właśnie przez Mieszka III; zob. idem, Mieszko III Stary i jego czasy, Wrocław 2002, s. 7). 


\section{Hipotetyczny model IV: „władczego namiestnictwa”}

Powyższa lista trzech modeli włączania młodszych dynastów piastowskich w zarząd terytorialny nie wyczerpuje wszystkich możliwości interpretacyjnych. Niewątpliwie brakuje na niej scenariusza, w którym książę dzielnicowy byłby obdarzony szerszymi kompetencjami niż zwykły namiestnik, a zarazem nie towarzyszyłby mu mianowany przez princepsa komes. W źródłach nie znajdziemy żadnego twardego dowodu zastosowania takiego wzorca postępowania w okresie istnienia drugiej monarchii piastowskiej, jednak biorąc pod uwagę, że w latach 1102-1107 polskim książętom i możnowładcom zmieściła się w głowach monarchia dwugłowa (dyarchia) w postaci współrządów Zbigniewa i Bolesława, za dopuszczalny należy uznać także ten hipotetyczny model czwarty, ,władczego namiestnictwa", w którym książę dzielnicowy byłby de facto udzielnym władcą, uznającym tylko generalne zwierzchnictwo princepsa. Nie można zresztą wykluczyć, że taki był właśnie status Mieszka Starego za pryncypatu Bolesława IV, ale pewności w tej mierze zyskać nie sposób ${ }^{28}$. Taki modus operandi mógł być zresztą nie tylko skutkiem jednorazowej decyzji, lecz także rezultatem dłuższego rozwoju, którego doskonały punkt wyjścia stanowiłoby „Zwykłe” namiestnictwo (model III).

\section{Podsumowanie i postulaty na przyszłość}

Z uwag przedstawionych wyżej wynika, że rzeczywistość ustrojowa drugiej monarchii piastowskiej była znacznie bardziej złożona, niż zwykło się uważać, a koncepcja Bieniaka o namiestniczym charakterze rządów młodszych Piastowiców w prowincjach wymaga doprecyzowania i rozbudowania. Na podstawie lektury kroniki Anonima zwanego Gallem można bowiem skonstatować, że już u schyłku rządów Władysława Hermana istniały trzy modele uposażania piastowskich juniorów: (1) model pierwszy, „zarządu dwutorowego", w którym piastowskiemu księciu towarzyszył komes strzegący interesów władcy zwierzchniego; (2) model drugi, „zdublowanego namiestnictwa”, w którym książę piastowski funkcjonował obok dotychczasowego komesa prowincji, będąc może uposażony udziałem w dochodach normalnie przypadających władcy zwierzchniemu; (3) „,zzysty” model namiestniczy (,ruski”), polegający na ustanowieniu „księcia krwi” namiestnikiem na takich zasadach jak możnowładcę. Modele owe zostały wyróżnione w oparciu o informacje dające się w sposób indukcyjny wyinterpretować z tekstu najstarszej polskiej kroniki; jedynie na zasadzie domysłów można próbować przenieść wyniki tej wstępnej analizy na sytuacje z późniejszego okresu, z którego pochodzą wprawdzie coraz liczniejsze źródła, niekoniecznie jednak naświetlające należycie problematykę historycznoustrojową. Nie sposób przy tym pozbyć się wrażenia, że zaprezentowane powyżej propozycje wyabstrahowane z kroniki Anonima zwanego Gallem to w istocie jedynie kazusy, ilustracje konkretnych rozwiązań z dziedziny zarzą-

28 O możliwym szczególnym statusie Mieszka pod rządami starszego brata por. uwagi Magdaleny Biniaś-Szkopek, Bolesław Kędzierzawy, s. 184-189. 
du terytorialnego wprowadzonych w życie przez uczestników politycznej gry pod wpływem przemożnych okoliczności. Jeśli więc na ich określenie używam pojęcia „modele”, jest to jedynie ekstrapolacja potrzebna po to, by prezentowany w niniejszym tekście problem w ogóle umieścić w agendzie badań mediewistycznych: jest bowiem kwestią przyszłych badań wyjaśnienie, czy i jak bardzo skrystalizowane i sformalizowane były metody ,zatrudniania” w zarządzie terytorialnym w XI-XII w. młodszych od w danym czasie panującego Piastowiców, czy i w jakim stopniu różniła się w tej mierze praktyka poszczególnych władców, czy też wreszcie - last but not least $-\mathrm{z}$ jakimi inspiracjami zewnętrznymi mieliśmy do czynienia w poszczególnych przypadkach.

$\mathrm{W}$ odniesieniu do pierwszego z zaprezentowanych modeli postępowania przez władcę zwierzchniego z młodszymi Piastowicami można podejrzewać inspirację niemiecką. $\mathrm{Na}$ to, że praktyka polityczna cesarzy z dynastii salickiej była nie bez znaczenia dla metod działania Władysława Hermana i jego zaufanego doradcy, Sieciecha, wskazał słusznie w swej przełomowej rozprawie Sławomir Gawlas. Jeden z elementów programu wzmocnienia władzy książęcej stanowiło rozbicie jednolitości władzy komesów w terytoriach poprzez dodanie im tzw. „przystawów” (pristaldi) zależnych tylko od księcia ${ }^{29}$. Nie należy oczywiście pochopnie przypuszczać, by w konkretnym przypadku „kohabitacji” księżyca Bolesława i komesa Wojsława ten drugi, bądź co bądź przedstawiciel najwyższego możnowładztwa, był li tylko „przystawem”; ze względu na dającą się wyczytać w kronice niską rangę tej funkcji uwłaczałoby to zarówno księciu, jak i komesowi. W przypadku rządów Bolesława Władysławica w prowincji wrocławskiej powinniśmy raczej liczyć się z recypowaniem instytucji terytorialnego palatyna, jako że przedmiotem wyjętym z zakresu kompetencji Bolesława było nie co innego niż sedes regni Wratislaviensis. Jest przy tym możliwe, że chwilowy sukces takiego konceptu w odniesieniu do młodszego syna - zniweczony wkrótce przez bunt obydwu potomków - zawdzięczał Władysław głównie młodemu wiekowi Bolesława.

Kwestią do wyjaśnienia w toku dalszych badań pozostaje, czy i w jakim stopniu model ten, z pewnością silnie promujący interesy władcy zwierzchniego, znalazł potem zastosowanie w newralgicznym, schyłkowym okresie istnienia drugiej monarchii, w szóstym i siódmym pokoleniu historycznych Piastów. Sądząc po efektach - nie znalazł, ewentualnie znalazł w niewielkim jedynie stopniu (kazus Piotra Włostowica, jeśli rzeczywiście był on palatynem wrocławskim). Świadczy to dość jednoznacznie o niewielkich możliwościach praktycznego wpływania na rządy w terytoriach przez książąt zwierzchnich w XII w. W tym samym duchu interpretować należy brak jednoznacznych świadectw recepcji w Polsce przed 1177 r. instytucji stanowiącej już za ostatnich Salijczyków niepośledni, a za pierwszych dwóch Sztaufów podstawowy instrument władzy królów niemieckich na wschód od Soławy: burgrafschaftu ${ }^{30}$. We wschodnich tery-

29 S. Gawlas, O ksztalt..., Warszawa 2000, s. 73-74; por. także: A. Krawiec, Król bez korony..., s. 189194; K. Benyskiewicz, Władysław Herman..., s. 139.

30 O początkach burgrafschaftów wschodnioniemieckich zob. W. Schlesinger, Zur Gerichtsverfassung des Markengebiets östlich der Saale im Zeitalter der deutschen Ostsiedlung, „Jahrbuch für die Geschichte Mittel- und Ostdeutschlands" 1953, nr 2, s. 59-62; H. Helbig, Der Wettinische Ständestaat: Untersuchungen zur Geschichte des Ständewesens und der landständischen Verfassung in Mitteldeutschland bis 1485 , Mitteldeutsche Forschungen, t. 4, Münster-Köln 1955, s. 204-273, passim; A. Thieme, Die Burggrafschaft Altenburg: Studien zu Amt und Herrschaft im Übergang vom hohen zum späten Mittelalter, Schriften zur Sächsischen Landesgeschichte, t. 2, Leipzig 2001, s. 152-163.

Artykuły - Articles 
toriach Rzeszy urząd ten odgrywał zresztą rolę szczególną - nie tylko ułatwiał władcom zarządzanie składnikami domeny, lecz także rozrywał jednolitość władzy margrabiów, tworząc swego rodzaju enklawy bezpośrednich wpływów królewskich. Mimo dużej, wydawałoby się, atrakcyjności tego wzorca organizacyjnego, pierwsze pewne świadectwa istnienia we władztwach piastowskich instytucji pana grodowego (łac. castellanus) pochodzą jednak dopiero z przełomu XII/XIII w. ${ }^{31}$ Zaledwie kilka enigmatycznych wzmianek może wskazywać na funkcjonowanie kasztelanów - przynajmniej w Krakowie ${ }^{32}$ i w Kruszwicy ${ }^{33}$ - już pod koniec istnienia jednolitej monarchii, za Bolesława IV i pierwszych rządów Mieszka $\mathrm{III}^{34}$. Jeśli jednak nawet pierwsza próba recepcji tej instytucji na gruncie polskim nastąpiła jeszcze przed kryzysem ustrojowym lat 1177-1180, to nie dotyczyła ona terytoriów zarządzanych przez piastowskich juniorów, lecz posiadłości princepsa, i w dodatku nie przyniosła trwałych rezultatów, skoro wszyscy kasztelanowie znani z późniejszych źródeł byli ustanowieni przez książąt dzielnicowych. Brak powodzenia książąt zwierzchnich w tym zakresie nie wydaje się przypadkiem; w piątym, szóstym i siódmym pokoleniu historycznych Piastów wszyscy władcy, którzy próbowali realizować program forsownego wzmocnienia władzy centralnej (Władysław I, Władysław II, Mieszko III), ponieśli przecież spektakularne klęski, a z powodzeniem na tronie utrzymywali się i plany swe realizowali jedynie ci, którzy sięgali po bardziej konsensualne środki władzy, nie antagonizując nadmiernie ani innych dynastów, ani możnowładztwa.

31 Do wzmianek źródłowych z lat 90. XII w. dotyczących Lubusza, Gniezna i Krakowa odsyła Bieniak, Polska elita..., cz. IVB, s. 35-37; najstarsze dokumenty śląskie wzmiankujące tamtejszych kasztelanów z początku XIII w. zob. SUB, t. 1, nr 77, 83, 87, 88, 93, 116, 117.

32 Por. J. Bieniak, Polska elita..., cz. IVB, s. 37; oraz Urzędnicy matopolscy XII-XV wieku: Spisy, red. A. Gąsiorowski, oprac. J. Kurtyka et al., Wrocław 1990, Urzędnicy dawnej Rzeczypospolitej XII-XVIII wieku: Spisy, red. A. Gąsiorowski, t. IV, z. 1, nr 108-109, s. 58-59; tam dalsze odsyłacze.

33 Kazus Kruszwicy jest o tyle zagmatwany, że lista osób, na której Piotr Wszeborzyc występuje jako wojewoda kujawski i kasztelan kruszwicki, znana jest z dwóch różnych źródeł: z księgi brackiej lubińskiej (zob. Księga bracka i nekrolog opactwa Panny Marii w Lubiniu, oprac. i koment. opatrzył Z. Perzanowski, Monumenta Poloniae Historica, Series II, t. 9, cz. 2, Warszawa 1976, s. 13) oraz z falsyfikatu mogileńskiego na imię Mieszka III (najnowsza edycja: M. Kosonowski, Dokumenty księżnej Salomei i księcia Mieszka Starego dla klasztoru Benedyktynów w Mogilnie z XVII-wiecznego kopiariusza Archiwum Krakowskiej Kapituly Katedralnej. Studium krytyczne i edycja tekstów [w:] Signa. Studia i szkice z nauk pomocniczych historii. Prace dedykowane Profesorowi Zenonowi Piechowi w sześćdziesiąta rocznicę urodzin, red. A. Marzec, M. Starzyński, Kraków 2014, „Studenckie Zeszyty Historyczne Koła Naukowego Historyków Studentów UJ”, z. 21, aneks 1, s. 48-58). W lubińskiej księdze brackiej odnośna lista osób opatrzona jest skądinąd dość wiarygodną datą 1176 (co starali się wykazać Krzysztof Mosingiewicz i Błażej Śliwiński w opracowaniu Rycerstwo polskie z końca XII w. w falsyfikacie Kazimierza Sprawiedliwego, „Kwartalnik Historyczny”, 1981, 88, z. 3, s. 720, passim), większość badaczy falsyfikatów mogileńskich skłonna jest natomiast datować całą tę listę na lata 90. XII w. (por. przegląd stanowisk i własne oryginalne rozwiązanie problemu datacji u M. Kosonowskiego, Dokumenty..., s. 40-44). Żadnej z tych ewentualności nie sposób a priori wykluczyć, przy czym to data 1176 jest bezpośrednio powiązana w źródle z tekstem przedmiotowej testacji, należy więc poważnie brać ją pod uwagę.

34 Teoretycznie można by dopuścić możliwość funkcjonowania w czasach Bolesława IV także kasztelanii wiskiej, co wydaje się jednak mało prawdopodobne w świetle argumentów przytoczonych przez Grzegorza Białuńskiego. Zob. idem, Wizna na pograniczu polsko-pruskim w czasach księcia Bolesława Kędzierzawego [w:] Pogranicze polsko-pruskie i krzyżackie. Materialy z konferencji naukowej Górzno 1-2 czerwca 2002 r., red. K. Grążawski, Włocławek-Brodnica 2003, s. 267-271. 
Do środków tego rodzaju należy zaliczyć oryginalny polski wynalazek, jakim był niewątpliwie drugi z wyróżnionych wyżej modeli zarządzania prowincją przez reprezentanta dynastii; w praktyce musiał on oznaczać częściowy przynajmniej demontaż władzy księcia zwierzchniego na danym terytorium i uszczuplenie dochodów czerpanych przezeń z danej prowincji. Na obecnym etapie badań pozostaje kwestią otwartą, $\mathrm{w}$ jakim stopniu model ten znalazł zastosowanie w praktyce politycznej XII stulecia. Można jednak domniemywać, że mógł on przyczyniać się do utrzymania labilnej równowagi między dynastią a możnowładztwem ${ }^{35}$, w związku z czym należy liczyć się z ewentualnością, że przynajmniej czasem władcy zwierzchni byli skłonni sięgać po to właśnie rozwiązanie. Waloru tego nie miał z pewnością model trzeci, czysto namiestniczy, w którym ,posadnicy” możnowładczej kondycji byliby zastępowani przez piastowskich „książąt krwi”. W przeciwieństwie do modelu drugiego nie umożliwiał on bowiem princepsowi ani ukontentowania najwyższych kręgów elity możnowładczej, ani szachowania przy ich pomocy uposażonych dzielnicami krewnych. Można zatem stwierdzić, że to właśnie czysto namiestniczy model był najkorzystniejszy z punktu widzenia książąt juniorów.

Nawet z powyższego, wstępnego przeglądu problematyki można także wysnuć wniosek, że Janusz Bieniak miał zapewne zasadniczą rację, proponując namiestnictwo, czasem z pozostawieniem na urzędzie komesa danej prowincji - tu wyróżnione jako model drugi i trzeci - jako zasadniczy wzorzec zarządzania prowincjami przez dynastów obowiązujący w drugiej monarchii Piastów. Jak często współegzystowali z sobą książę i komes, jest niestety niemal niesprawdzalne, gdyż większość naszych informacji o elicie prowincjonalnej z XII w. wywodzi się z pozbawionych określeń urzędowych testacji. Sprawia to, że współczesny czytelnik musi przeważnie sam wykoncypować, jaką funkcję mógł pełnić pierwszy po księciu dzielnicowym możnowładca świecki danej prowincji - zależnie więc od tego, czy sięgnie on po koncepcję Józefa Sporsa, Janusza Bieniaka czy Tadeusza Lalika, ta sama osoba może zostać przezeń zinterpretowana jako książęcy komornik, komes-kasztelan bądź komes-palatyn. Niemniej jednak dominacja w praktyce modeli drugiego i trzeciego nad pierwszym wydaje się nie ulegać wątpliwości, co każe powątpiewać w unoszące się od dawna nad polską mediewistyką widmo „piastowskiego despotyzmu". Nie inaczej niż władcy sąsiednich Niemiec czy Czech, piastowscy książęta zwierzchni skazani byli na sprawowanie rządów w stylu konsensualnym ${ }^{36}$,

35 O szczególnym znaczeniu tej kwestii zob. S. Gawlas, $O$ ksztalt.., s. 74, 79, passim.

36 Pojęcie władztwa konsensualnego (konsensuale Herrschaft) wprowadził Bernd Schneidmüller, opierając się na doświadczeniach historycznych Niemiec (B. Schneidmüller, Konsensuale Herrschaft. Ein Essay über Formen und Konzepte politischer Ordnung im Mittelalter [w:] Reich, Regionen und Europa in Mittelalter und Neuzeit. Festschrift für Peter Moraw, ed. P.-J. Heinig, Berlin 2000, s. 53-87); rozwój tego modelu w praktyce politycznej Rzeszy w interesującym nas okresie ukazała Jutta Schlick (zob. eadem, König, Fürsten und Reich (1056-1159). Herrschaftsverständnis im Wandel, Mittelalter-Forschungen, Vol. 7, Stuttgart 2001). Szczupłość źródeł dotyczących Polski piastowskiej nie pozwala na równie dogłębny portret, lecz dzięki opracowaniu przez Janusza Bieniaka zagadnienia roli możnowładztwa i jego relacji z dynastią panującą w XII w. można z dużą dozą pewności stwierdzić, że możni nienależący do dynastii stanowili w pewnym stopniu podmiot współrządzący krajem; warto tu zresztą zaznaczyć, że nawet Karol Modzelewski, czołowy orędownik tezy o silnych podstawach władzy książęcej i słabości gospodarczej możnowładztwa w Europie Środkowo-Wschodniej w XI-XII w., twierdził, że monarchie te były „bliższe pojęciu oligarchii arystokratycznych niż despotii” (K. Modzelewski, Chtopi..., s. 159). 
w przymierzu ze społeczną elitą, na którą składali się inni Piastowie ${ }^{37}$ oraz czołówka możnowładztwa ${ }^{38}$.

Próby odejścia od tego sposobu rządów w kierunku instytucjonalizacji bezpośredniego wpływu władcy zwierzchniego w prowincjach za każdym razem kończyły się klęską; na tym froncie dziedziczni władcy piastowscy ,polegli” właściwie już na progu drogi, którą elekcyjni władcy Niemiec kroczyli z powodzeniem przez ponad stulecie. W różnicy statusu juniorów piastowskich i terytorialnych władców niemieckich może się skądinąd kryć wyjaśnienie całego problemu: namiestnik prowincji pochodzący z dynastii, choćby formalnie niczym nie różnił się od swego odpowiednika kondycji możnowładczej, automatycznie stawał się kimś więcej ${ }^{39}$, kimś, komu książę zwierzchni nie mógł narzucić zbyt silnej kontroli, nie urażając go i nie popychając do buntu. Nie wydaje się zatem przypadkiem, że prawdopodobny i ewentualny przykład zastosowania wyróżnionego wyżej modelu pierwszego dotyczyły osoby niepełnoletniej (Bolesław Władysławic we Wrocławiu) i syna princepsa obejmującego władzę w prowincji bezpośrednio po nim (Bolesław Wysoki); z perspektywy książąt zwierzchnich okoliczności te minimalizowały ryzyko buntu, dla samych juniorów, zaczynających dopiero władcze kariery, nie będąc koniecznie ujmą na honorze.

Konkludując, stwierdzić należy, że już za panowania Władysława Hermana znane były w dynastii Piastów co najmniej trzy sposoby ,zatrudniania” w zarządzie terytorialnym monarchii dynastów niebędących książętami zwierzchnimi, w związku z czym całą późniejszą historię drugiej monarchii piastowskiej - co najmniej do 1177 r., gdy nastąpił pierwszy wielki krach pryncypatu - należałoby krytycznie przejrzeć pod kątem zastosowania tych modeli w praktyce, ewentualnie także zidentyfikować inne stosowane przez władców zwierzchnich strategii działania. Spojrzenie na dzieje drugiej monarchii Piastów z tej właśnie perspektywy może ułatwić dokładniejsze zarysowanie faktycznego przebiegu zmagań politycznych i przemian ustrojowych, które jednolite władztwo przemieniły w konglomerat księstw dzielnicowych.

\section{Bibliografia}

\section{Wydawnictwa źródłowe}

Galli Anonymi cronica et gesta ducum sive principum Polonorum, wydał, wstępem i koment. opatrzył K. Maleczyński, Monumenta Poloniae Historica, Series II, t. 2, Kraków 1952.

37 Funkcjonowanie w świadomości elit pierwszej i drugiej monarchii piastowskiej oraz innych współczesnych im ośrodków władzy roszczenia wszystkich członków rodu panującego do udziału we władzy dobitnie podniósł ostatnio Zbigniew Dalewski (Modele..., passim). Por. także trafne słowa J. Bieniaka, Polska elita..., cz. I, s. 48: „W opinii społecznej oni bowiem [scil. dynaści piastowscy - KF] byli czynnikiem najbardziej uprawnionym do współwładzy (domini naturales); administracja ziem przez kasztelanów [recte: komesów - KF] naczelnych grodów stanowiła jedynie konieczny substytut w razie ich braku".

38 O ambicjach i znaczeniu możnowładztwa polskiego końca XI-XII w. por. trzeźwe uwagi Sławomira Gawlasa, O ksztatt..., s. 76-79.

39 Por. J. Bieniak, Polska elita..., cz. I, s. 42. 
Kronika Polska (Chronica Polonorum), wyd. L. Ćwikliński, Monumenta Poloniae Historica, t. 3, Lwów 1878 s. 578-656.

Księga bracka i nekrolog opactwa Panny Marii w Lubiniu, oprac. i koment. opatrzył Z. Perzanowski, Monumenta Poloniae Historica, Series II, t. 9, cz. 2, Warszawa 1976, s. 3-14.

Liber formularum ad ius canonicum spectantium, ex actis Jacobi de Kurdwanow episcopi Plocensis maxima parte depromptarum, wyd. B. Ulanowski, Archiwum Komisji Prawniczej, t. 1, s. $1-31$.

Magistri Vincentii dicti Kadłubek Chronica Polonorum, wyd. M. Plezia, Monumenta Poloniae Historica, Series II, t. 9, Kraków 1994.

Schlesisches Urkundenbuch, t. 1.971-1230, hrsg. J.J. Menzel, H. Appelt, bearb. H. Appelt, KölnGraz 1963.

\section{Opracowania}

Benyskiewicz K., Władysław Herman. Ksiązę Polski 1079-1102, Kraków 2014.

Białuński G., Wizna na pograniczu polsko-pruskim w czasach księcia Bolesława Kędzierzawego [w:] Pogranicze polsko-pruskie i krzyżackie. Materiały z konferencji naukowej Górzno 1-2 czerwca 2002 r., red. K. Grążawski, Włocławek-Brodnica 2003, s. 255-276.

Bieniak J., Polska elita polityczna XII wieku, cz. I: Tło działalności [w:] Społeczeństwo Polski średniowiecznej, t. 2, red. S.K. Kuczyński, Warszawa 1982, s. 11-61.

Bieniak J., Polska elita polityczna XII wieku, cz. IIIA: Arbitrzy książat - krag rodzinny Piotra Włostowica [w:] Społeczeństwo Polski średniowiecznej, t. 4, red. S.K. Kuczyński, Warszawa 1990, s. 13-107.

Bieniak J., Polska elita polityczna XII wieku, cz. IVB: Dwa możnowładztwa - starzy i nowi [w:] Społeczeństwo Polski średniowiecznej. Zbiór studiów, t. 12, red. S. Górzyński, Warszawa 2012, s. 11-45.

Bieniak J., Powstanie księstwa opolsko-raciborskiego jako wyraz przeksztatcania się Polski $w$ dzielnicowa poliarchie [w:] Sacra Silentii provincia. 800 lat dziedzicznego księstwa opolskiego (1202-2002), red. A. Pobóg-Lenartowicz, Opole 2003, s. 37-81.

Biniaś-Szkopek M., Bolesław Kędzierzawy, Poznań 2014.

Cetwiński M., Kasztelanowie i kasztelanie na Ślasku w XIII i XIV wieku [w:] Studia z dziejów średniowiecza polskiego i powszechnego, Acta Universitatis Wratislaviensis, T. 979, Historia, t. 69, Wrocław 1989, s. 3-20 (tekst ponownie opublikowany w zbiorze: M. Cetwiński, Śląski tygiel. Studia z dziejów polskiego średniowiecza, Częstochowa 2001, s. 255-275).

Dalewski Z., Modele władzy dynastycznej w Europie Środkowo-Wschodniej we wcześniejszym średniowieczu, Warszawa 2014.

Dąbrowski F., Studia nad administracją kasztelańska Polski XIII wieku, Warszawa 2007.

Dowiat J., Polska - państwem średniowiecznej Europy, Warszawa 1968.

Eberl I., Pfalzgraf [w:] Lexikon des Mittelalters, t. 6, szp. 2011-2013.

Fokt K., Denuo de Legenicensi potestate. Uwagi o znaczeniu Legnicy w księstwie Bolesława Wysokiego, „Śląski Kwartalnik Historyczny Sobótka” 2015, R. 70, nr 2, s. 3-15.

Font M., Im Spannungsfeld der christlichen Großmächte. Mittel- und Osteuropa im 10.-12. Jahrhundert, Herne 2008.

Gawlas S., O ksztalt zjednoczonego Królestwa. Niemieckie władztwo terytorialne a geneza społeczno-ustrojowej odrębności Polski, wyd. 2, Warszawa 2000 (wyd. 1: Warszawa 1996).

Grodecki R., Zbigniew ksiązę Polski [w:] Studja staropolskie. Księga ku czci Aleksandra Brücknera, Kraków 1928, s. 71-105.

Jurek T., [rec.] J. Osiński, Statut Bolestawa Krzywoustego, Wydawnictwo Avalon, Kraków 2014, ss. 272, „Roczniki Historyczne” 2015, t. 81, s. 230-233.

Artykuły - Articles 
Helbig H., Der Wettinische Ständestaat: Untersuchungen zur Geschichte des Ständewesens und der landständischen Verfassung in Mitteldeutschland bis 1485, Mitteldeutsche Forschungen, t. 4, Münster-Köln 1955.

Kosonowski M., O ustawie sukcesyjnej Bolesława Krzywoustego w kontrowersyjnym oświetleniu. W zwiąku z praca Jacka Osińskiego Statut Bolesława Krzywoustego, Wydawnictwo Avalon, Kraków 2014, ss. 271 i 5 tablic, CPH 2015, t. 67, nr 2, s. 237-269.

Kosonowski M., Dokumenty księżnej Salomei i księcia Mieszka Starego dla klasztoru Benedyktynów w Mogilnie z XVII-wiecznego kopiariusza Archiwum Krakowskiej Kapituły Katedralnej. Studium krytyczne i edycja tekstów [w:] Signa. Studia i szkice z nauk pomocniczych historii. Prace dedykowane Profesorowi Zenonowi Piechowi w sześćdziesiata rocznice urodzin, red. A. Marzec, M. Starzyński, Kraków 2014, „Studenckie Zeszyty Historyczne Koła Naukowego Historyków Studentów UJ", z. 21, s. 29-58.

Kotljar M.F., Rička V.M., Knjažyj dvir Pivdennoj Rusi X-XIII st., Kyiv 2008.

Krawiec A., Król bez korony. Władysław I Herman książe polski, Warszawa 2014.

Labuda G., Władystaw i Zbigniew. U genezy podziałów dzielnicowych $w$ Polsce $w$ drugiej połowie XI wieku [w:] Społeczeństwo Polski średniowiecznej, t. 6, red. S.K. Kuczyński, Warszawa 1994, s. 9-21.

Lalik T., Sandomierskie we wcześniejszym średniowieczu. Prowincja, księstwo, województwo [w:] Studia sandomierskie. Materiały do dziejów miasta Sandomierza i regionu sandomierskiego, red. T. Wąsowicz; J. Pazdur, Warszawa 1967, s. 41-109.

Łowmiański H., Początki Polski, t. VI: Polityczne i społeczne procesy kształtowania się narodu do początku wieku XIV, cz. 1, Warszawa 1985.

Łowmiański H., Rozdrobnienie feudalne Polski w historiografii naukowej [w:] Polska w okresie rozdrobnienia feudalnego, red. H. Łowmiański, Wrocław 1973, s. 7-34.

Maleczyński K., Bolesław Krzywousty: zarys panowania, Kraków 1947.

Maleczyński K., Śląsk w okresie od schytku IX do połowy XII wieku [w:] Historia Ślaska, T. 1: Do roku 1763, cz. 1: Do połowy XIV w., red. K. Maleczyński, Wrocław 1960, s. 145-237.

Modzelewski K., Organizacja gospodarcza państwa piastowskiego X-XIII wiek, wyd. 2, Poznań 2000 (wyd. 1: Wrocław 1975).

Modzelewski K., Chłopi w monarchii wczesnopiastowskiej, T. 1 serii Chłopi w społeczeństwie polskim, red. Cz. Madajczyk, Wrocław 1987.

Mosingiewicz K., Śliwiński B., Rycerstwo polskie z końca XII w. w falsyfikacie Kazimierza Sprawiedliwego, „Kwartalnik Historyczny” 1981, T. 88, nr 3, s. 713-722.

Paulus Ch., Das Pfalzgrafenamt in Bayern im frühen und hohen Mittelalter, Kommission für bayerische Landesgeschichte: Studien zur bayerischen Verfassungs- und Sozialgeschichte, Arbeiten aus der historischen Atlasforschung in Bayern, T. 25, München 2007.

Schlesinger W., Zur Gerichtsverfassung des Markengebiets östlich der Saale im Zeitalter der deutschen Ostsiedlung, ,Jahrbuch für die Geschichte Mittel- und Ostdeutschlands” 1953, nr 2, s. $1-93$.

Schlick J., König, Fürsten und Reich (1056-1159). Herrschaftsverständnis im Wandel, Mittelalter-Forschungen, Vol. 7, Stuttgart 2001.

Schneidmüller B., Konsensuale Herrschaft. Ein Essay über Formen und Konzepte politischer Ordnung im Mittelalter [w:] Reich, Regionen und Europa in Mittelalter und Neuzeit. Festschrift für Peter Moraw, ed. P.-J. Heinig, Berlin 2000, s. 53-87.

Spors J., Podział dzielnicowy Polski według statutu Bolesława Krzywoustego ze szczególnym uwzględnieniem dzielnicy seniorackiej, Słupsk 1978.

Spors J., Uwagi nad geneza urzędu wojewody dzielnicowego w Polsce XII - początku XIII wieku, „Przegląd Historyczny” 1991, R. 82, nr 2, s. 185-208.

Spors J., Wojewodowie Polski dzielnicowej w XII i XIII wieku: Przegląd wojewodów w kontekście ewolucji urzędu od godności nadwornej do urzędu ziemskiego, „Przegląd Historyczny” 1991, R. 82, nr 3-4, s. 353-370. 
Spors J., Ze studiów nad urzędami w Polsce XI i XII w. (wojewoda, komornik, podkomorzy), CPH 1992 (wyd. 1993), t. 44, nr 2, s. 25-53.

Strätz H.-W., Pfalzgraf [w:] Handwörterbuch zur deutschen Rechtsgeschichte, wyd. 1, t. 3, szp. 1667-1670.

Teterycz-Puzio A., Henryk Sandomierski. Polski krzyżowiec (1126/1133 - 18 X 1166), wyd. 2, Kraków 2015.

Thieme A., Die Burggrafschaft Altenburg: Studien zu Amt und Herrschaft im Übergang vom hohen zum späten Mittelalter, Schriften zur Sächsischen Landesgeschichte, T. 2, Leipzig 2001.

Urzędnicy matopolscy XII-XV wieku. Spisy, red. A. Gąsiorowski, oprac. J. Kurtyka et al., Wrocław 1990.

Urzędnicy dawnej Rzeczypospolitej XII-XVIII wieku. Spisy, oprac. A. Gąsiorowski, T. 4. Małopolska, z. 1.

Wasilewski T., Poland's Administrative Structure in Early Piast Times: Castra Ruled by Comites as Centres of Provinces and Territorial Administration, Acta Poloniae Historica 1989, Vol. 44, s. 5-31.

Wenta J., O stróżach „testamentu” Bolesława Krzywoustego [w:] Społeczeństwo Polski średniowiecznej, T. 8, red. S.K. Kuczyński, Warszawa 1999, s. 67-112.

Wiszewski P., Mieszko III Stary i jego czasy, Wrocław 2002.

Zotz Th., Im Amt und Würden: Zur Eigenart „offizieller” Positionen im früheren Mittelalter, „Tel Aviver Jahrbuch für deutsche Geschichte" 1993, nr 22, s. 1-23.

Zotz Th., Burggraf [w:] Handwörterbuch zur deutschen Rechtsgeschichte, wyd. 2, t. 1, szp. 766768.

Żerelik R., Dzieje Śląska do 1526 roku [w:] Historia Ślaska, red. M. Czapliński, Wrocław 2002, s. $14-116$. 